\title{
Metabolism of boar spermatozoa before, during preparation for, and after storage in liquid nitrogen
}

\author{
T. O’Shea*, J.-L. Dacheux $\dagger$ and M. Paquignon $\ddagger$
}

I.N.R.A. Station de Physiologie de la Reproduction, Nouzilly 37380, $\nmid$ Laboratoire Physiologie Comparée, Faculté des Sciences, Tours 37000, and $\ddagger$ I.T.P., 149 Rue de Bercy, Paris $12^{\mathrm{e}}$, France

Summary. Boar spermatozoa incorporated more $\left[{ }^{14} \mathrm{C}\right]$ glycerol into lipid when incubated with $200 \mathrm{mM}$ - than with $25 \mathrm{~mm}$-glycerol. Measurements were made of the metabolism of spermatozoa while they were being prepared for frozen storage. $\left[{ }^{14} \mathrm{C}\right]-$ Glucose was converted to $\mathrm{CO}_{2}$ and lipid while the cells were cooling to $15^{\circ} \mathrm{C}$. Glycerol was added at $15^{\circ} \mathrm{C}$ and during further cooling to $5^{\circ} \mathrm{C}$ glucose metabolism was greatly reduced but $\left[{ }^{14} \mathrm{C}\right]$ glycerol was converted to $\mathrm{CO}_{2}$ and lipid. Under aerobic conditions spermatozoa accumulated lactate while cooling from 30 to $15^{\circ} \mathrm{C}$ and from 15 to $5^{\circ} \mathrm{C}$. With essentially anaerobic conditions, although more lactate was accumulated this occurred only while the cells were cooling from 30 to $15^{\circ} \mathrm{C}$, and no further accumulation could be detected during cooling from 15 to $5^{\circ} \mathrm{C}$. When boar spermatozoa were incubated at $37^{\circ} \mathrm{C}$ after storage in liquid nitrogen, metabolism of glycerol was greater than metabolism of glucose. It is suggested that this preferential use of glycerol during cooling and after storage may be one facet of its cryoprotective function. After storage, boar spermatozoa incorporated relatively less $\left[{ }^{14} \mathrm{C}\right]$ stearic and $\left[{ }^{14} \mathrm{C}\right]$ palmitic acids into phospholipids (especially phosphatidyl choline) than did freshly collected cells. Caffeine stimulated the oxygen uptake of freshly collected and thawed cells.

\section{Introduction}

The technology for the storage of spermatozoa has been largely derived from empirical experimentation (Smith, 1961). In general, a wide scan is made of the manipulations needed in vitro to prepare the spermatozoa for freezing, and then the processes judged to be most favourable are utilized for fertility trials. This procedure has been followed by several groups investigating the storage of boar semen (Paquignon \& du Mesnil du Buisson, 1973; Wilmut \& Polge, 1974; Larsson \& Einarsson, 1975; Pursel \& Johnson, 1975; Osinowo \& Salamon, 1976), and the resulting methods are characterized by great heterogeneity (reviewed by Einarsson, 1973; Paquignon \& du Mesnil du Buisson, 1973), particularly for the amount of glycerol used although the mode of action of glycerol has not yet been fully elucidated (Einarsson, 1973).

To clarify some aspects of storage technology, metabolic studies of boar spermatozoa were carried out in relation to one storage procedure which had been derived from motility studies in vitro and which gave satisfactory fertility in the field (Paquignon \& Courot, 1976).

\section{Materials and Methods}

\section{General methods}

Sperm samples. Whole ejaculates were collected manually, filtered through gauze, and the seminal plasma was removed after centrifugation at $900 \mathrm{~g}$ at $28^{\circ} \mathrm{C}$ for $10 \mathrm{~min}$. The percentage of motile spermatozoa was estimated with phase-contrast microscopy at $37^{\circ} \mathrm{C}$.

* Present address: Department of Physiology, University of New England, Armidale, New South Wales, Australia. 
Freezing and thawing of spermatozoa. These processes were essentially as proposed by Paquignon \& Courot (1975). The spermatozoa, after separation from seminal plasma, were diluted at $28^{\circ} \mathrm{C}$ with a diluent based on egg yolk and glucose (Polge, Salamon \& Wilmut, 1970) such that $275 \mathrm{~mm}$-glucose was present after mixing. The semen was cooled to $15^{\circ} \mathrm{C}$ in a $100 \mathrm{ml}$ tube over a $1 \mathrm{~h}$ period and maintained at $15^{\circ} \mathrm{C}$ for $4 \mathrm{~h}$. It was then diluted a second time with the same diluent but containing glycerol to give final concentrations of $280-290 \mathrm{~mm}$-glucose, $2 \%$ $(\mathrm{v} / \mathrm{v})$ glycerol and $600-800 \times 10^{6}$ spermatozoa $/ \mathrm{ml}$. The mixture was cooled to $5^{\circ} \mathrm{C}$ over $1 \mathrm{~h}$ and frozen into pellets $(0.1 \mathrm{ml})$ on solid $\mathrm{CO}_{2}$ before transfer to liquid nitrogen. Thawing of the pellets was effected by their addition to 5 volumes of INRA-ITP thawing diluent at $50^{\circ} \mathrm{C}$ (Paquignon \& du Mesnil du Buisson, 1973). This thawing diluent contained 1000 i.u. penicillin $/ \mathrm{ml}, 1 \mathrm{mg}$ streptomycin $/ \mathrm{ml}, 17 \mathrm{~mm}$-glucose, $68 \mathrm{~mm}$-sodium citrate, $25 \mathrm{~mm}$-sodium bicarbonate, $5.4 \mathrm{~mm}$ $\mathrm{KCl}$ and $9.9 \mathrm{~mm}$-EDTA.

Incubation conditions. Except when oxygen uptake was being measured, incubations were carried out in $10 \mathrm{ml}$ conical flasks fitted with air-tight stoppers and hanging wells. Isotopically labelled substrates were added in volumes of $10 \mu \mathrm{l}$. The [U- $\left.{ }^{14} \mathrm{C}\right]$ glucose (sp. act. $238 \mathrm{mCi} / \mathrm{mmol}$ ) was purchased from CEA (France). The $\left[1,5-{ }^{14} \mathrm{C}\right]$ citric acid monohydrate $(27 \mathrm{mCi} / \mathrm{mmol})$, [U$\left.{ }^{14} \mathrm{C}\right]$ glycerol $(46 \mathrm{mCi} / \mathrm{mmol}), \mathrm{L}-\left[\mathrm{U}-{ }^{14} \mathrm{C}\right]$ lactic acid $(61 \mathrm{mCi} / \mathrm{mmol})$, DL- $\left[1-{ }^{14} \mathrm{C}\right]$ lactic acid $(37$ $\mathrm{mCi} / \mathrm{mmol})$, DL- $\left[2{ }^{14} \mathrm{C}\right]$ lactic acid $(29 \mathrm{mCi} / \mathrm{mmol}),\left[\mathrm{U}-{ }^{14} \mathrm{C}\right] \mathrm{palmitic}$ acid $(256 \mathrm{mCi} / \mathrm{mmol})$, sodium $\left[{ }^{14} \mathrm{C}\right]$ bicarbonate $(59 \mathrm{mCi} / \mathrm{mmol})$, and $\left[\mathrm{U}-{ }^{14} \mathrm{C}\right]$ stearic acid $(102 \mathrm{mCi} / \mathrm{mmol})$ were from the Radiochemical Centre (Amersham).

Metabolic studies. The methods described by Dacheux, O'Shea \& Paquignon (1979) were used to determine the total lactate accumulation (enzymically with lactic dehydrogenase), the $\left[{ }^{14} \mathrm{C}\right]$ lactate produced from $\left[{ }^{14} \mathrm{C}\right]$ glucose and the $\left[{ }^{14} \mathrm{C}\right]$ glucose utilized (after separation of the glucose and lactate in the reaction medium by paper chromatography), and the production of $\mathrm{CO}_{2}$ and lipid from isotopically labelled substrates. Incorporation of sodium $\left[{ }^{14} \mathrm{C}\right]$ bicarbonate was measured as described by O'Shea \& Wales (1970). The incorporation of $\left[\mathrm{U}-{ }^{14} \mathrm{C}\right]$ stearic and $\left[\mathrm{U}-{ }^{14} \mathrm{C}\right]$ palmitic acids into individual lipids was measured by extracting the total lipids from the reaction medium (see Dacheux et al., 1979). Aliquots of the total lipid extract from each duplicate were separated by thin-layer chromatography on pre-coated silica gel plates (60F 254 Merck). The plates were eluted with chloroform:methanol:water (58:39:2 by vol.) until the front was about halfway. After drying, the plates were then run their entire length in the same direction with chloroform. Standards (Koch Light) were run at the same time, and the lipid spots were then detected with iodine vapour. The bands of silica gel were scraped into $1 \mathrm{ml}$ methanol and the radioactivity counted.

\section{Experiment $A$}

For these preliminary experiments to determine the effects of the incubation conditions and what to use for control samples, the spermatozoa were centrifuged from the seminal plasma and

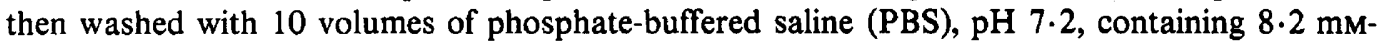
$\mathrm{Na}_{2} \mathrm{HPO}_{4}, 1.5 \mathrm{~mm}-\mathrm{KH}_{2} \mathrm{PO}_{4}, 2.7 \mathrm{~mm}-\mathrm{KCl}, 0.5 \mathrm{~mm}-\mathrm{MgCl}_{2}, 0.9 \mathrm{~mm}-\mathrm{CaCl}_{2}, 138 \mathrm{~mm}-\mathrm{NaCl}, 1000$ i.u. penicillin $/ \mathrm{ml}$ and $1 \mathrm{mg}$ streptomycin $/ \mathrm{ml}$. Immotile cells were obtained by immersing an aliquot of the spermatozoa in liquid nitrogen. Supernatants from motile and immotile spermatozoa were obtained by collecting the supernatant from above centrifuged cells. The washed spermatozoa $(0.5 \mathrm{ml})$ were added to $0.5 \mathrm{ml}$ PBS containing the isotopically labelled glucose or glycerol, the desired concentration of glucose or glycerol, and cell supernatants where appropriate. The samples were incubated with gentle shaking at $37^{\circ} \mathrm{C}$.

\section{Experiment B: metabolism during cooling}

Aliquots $(2 \mathrm{ml})$ of the appropriate semen mixture (as described above for the freezing and thawing of spermatozoa) were incubated in $10 \mathrm{ml}$ conical flasks with labelled glucose or labelled glycerol and under the time and temperature conditions existing during each stage of the freezing 
process. During the first stage (B1), i.e. cooling from 28 to $15^{\circ} \mathrm{C}$ and maintenance at $15^{\circ} \mathrm{C}$ for 4 $\mathrm{h}$, only $\left[\mathrm{U}^{14} \mathrm{C}\right]$ glucose was added. During the second stage (B2), i.e. cooling from 15 to $5^{\circ} \mathrm{C}$ over $1 \mathrm{~h}$, separate incubation flasks were set up to contain $\left[\mathrm{U}-{ }^{14} \mathrm{C}\right]$ glucose or $\left[\mathrm{U}-{ }^{14} \mathrm{C}\right]$ glycerol. For the third stage (B3), $\left[\mathrm{U}-{ }^{14} \mathrm{C}\right]$ glucose or $\left[\mathrm{U}-{ }^{14} \mathrm{C}\right]$ glycerol were added at $5^{\circ} \mathrm{C}$ to aliquots before they were pelleted on solid $\mathrm{CO}_{2}$. After storage these pellets were thawed by their addition (a few at a time) to $0.2 \mathrm{ml} 6 \mathrm{~N}-\mathrm{H}_{2} \mathrm{SO}_{4}$.

The controls for determination of background radioactivity consisted of the incubation, under the same conditions, of the labelled substrates with the appropriate diluent mixtures and spermatozoa made immotile by plunging into liquid nitrogen.

\section{Experiment C: metabolism of spermatozoa before and after storage at $-196^{\circ} \mathrm{C}$}

In this experiment the metabolism of thawed cells and of freshly collected spermatozoa were compared under similar conditions to those at which post-thawing motility tests had been carried out in deriving the storage technique.

Pellets of spermatozoa which had been frozen for at least 2 days in liquid nitrogen were thawed in the INRA-ITP thawing diluent and then aliquots $(2 \mathrm{ml})$ were incubated with $\left[\mathrm{U}-{ }^{14} \mathrm{C}\right.$ ]glucose $(1 \mu \mathrm{Ci}),\left[\mathrm{U}-{ }^{14} \mathrm{C}\right]$ glycerol $(1 \mu \mathrm{Ci}),\left[1{ }^{14} \mathrm{C}\right]$ sodium lactate $(0.25 \mu \mathrm{Ci}),\left[2-{ }^{14} \mathrm{C}\right]$ sodium lactate $(0.25 \mu \mathrm{Ci}),\left[1,5-{ }^{14} \mathrm{C}\right]$ citric acid $(0.65 \mu \mathrm{Ci}),\left[\mathrm{U}-{ }^{14} \mathrm{C}\right]$ stearic acid $(0.1 \mu \mathrm{Ci})$, [U- ${ }^{14} \mathrm{C}$ ]palmitic acid $(0.1 \mu \mathrm{Ci})$, or sodium $\left[{ }^{14} \mathrm{C}\right.$ ]bicarbonate $(5 \mu \mathrm{Ci})$. From an aliquot (about one-third of the ejaculate) of each ejaculate that was stored in liquid nitrogen the spermatozoa were centrifuged from the seminal plasma and resuspended in a mixture of the same cooling, freezing, and thawing diluents that was used for storage and thawing of that ejaculate. Aliquots $(2 \mathrm{ml})$ of these recently ejaculated cells were incubated at $37^{\circ} \mathrm{C}$ with the labelied substrates. Control samples consisted of spermatozoa rendered immotile by immersion in liquid nitrogen. During incubation the medium contained 60-70 mM-glucose, 42-47 mM-glycerol, $57 \mathrm{~mm}$-sodium citrate and about $20 \mathrm{~mm}$-sodium bicarbonate.

Oxygen uptake was measured at $37^{\circ} \mathrm{C}$ in a 'Clark'-type oxygen electrode which was calibrated by the method of Robinson \& Cooper (1970). New samples were taken every hour from about $100 \mathrm{ml}$ of a suspension of the spermatozoa maintained at $37^{\circ} \mathrm{C}$ with gentle shaking. The effect of $0.6 \mathrm{~mm}$-caffeine on oxygen uptake was examined by adding caffeine to the subsamples in the electrode, and not to the bulk sample.

\section{Statistical analysis and presentation of results}

The significance of the results was assessed by analysis of variance or by paired $t$ test.

In Exp. B, because there was heterogeneity of variance in the raw data, logarithmic values of the data for experimental and control flasks were compared and the results presented in the text are the differences so obtained. The results of Exp. B1 were analysed separately, whereas the data for glucose and glycerol for Exps B2 and B3 were assessed together. For Exp. C, the data analysed were the differences between the experimental and the control values. Data for the incorporation of $\left[\mathrm{U}-{ }^{14} \mathrm{C}\right]$ stearic and $\left[\mathrm{U}-{ }^{14} \mathrm{C}\right]$ palmitic acids could not be calculated on a gravimetric basis because the amounts of these fatty acids in native egg yolk were not known. These resuits are presented as percentages of the total isotope incorporated into lipid.

\section{Results}

\section{Experiment $A$}

The main results from this series of experiments are summarized below.

The incorporation of glycerol into lipids (mean \pm s.e.m.) increased with time when the

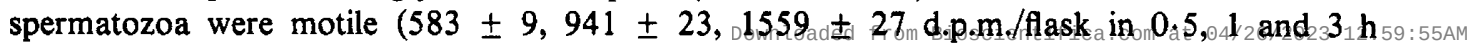


respectively) but was constant when the spermatozoa were rendered immotile by immersion in liquid nitrogen ( $110 \pm 4,115 \pm 1,122 \pm 3 \mathrm{~d} . \mathrm{p} . \mathrm{m}$./flask in $0 \cdot 5,1$ and $3 \mathrm{~h}$ respectively).

The addition of washed, immotile spermatozoa to motile spermatozoa decreased $(P<0.05)$ the mean ( \pm s.e.m.) amount of glucose oxidized to $\mathrm{CO}_{2}\left(2235 \pm 137 \mathrm{mmol} \mathrm{CO} \mathrm{CO}_{2} / 10^{8}\right.$ motile spermatozoa in $3 \mathrm{~h}$ with $60 \%$ motile spermatozoa, $1815 \pm 27$ with $40 \%$ motile cells, $1483 \pm 96$ with $20 \%$ motile cells). When motile spermatozoa were incubated with the supernatant from a sample of centrifuged motile cells they formed more $(P<0.05) \mathrm{CO}_{2}$ from $50 \mathrm{~mm}$-glycerol $(304$ $\pm 2 \mathrm{nmol} \mathrm{CO} 2 / 10^{8}$ motile cells) than did motile spermatozoa incubated with the supernatant from immotile cells $\left(210 \pm 28 \mathrm{nmol} \mathrm{CO} / 10^{8}\right.$ motile cells).

The effect of the concentration of glucose or glycerol was investigated. In an experiment with three ejaculates, the highest substrate values used were similar to those used during the freezing of boar semen. There was increased oxidation of glycerol to $\mathrm{CO}_{2}$ with rising glycerol concentrations of $25,50,100$ and $200 \mathrm{~mm}\left(440 \pm 18,758 \pm 81,862 \pm 9\right.$, and $1129 \pm 191 \mathrm{nmol} \mathrm{CO} / 10^{8}$ motile cells in $3 \mathrm{~h}$ respectively). Glucose oxidation was unaffected by similar changes in its concentration.

\section{Experiment B: metabolism during cooling}

As shown in Table 1, during cooling from 28 to $15^{\circ} \mathrm{C}$ boar spermatozoa oxidized glucose to $\mathrm{CO}_{2}$ and incorporated glucose into lipid. During cooling from 15 to $5^{\circ} \mathrm{C}$ oxidation of both substrates occurred $(P<0.01)$; the difference between glucose and glycerol oxidation was not significant as it varied between ejaculates (substrate $\times$ boars interaction: $P<0.01$ ). In the analysis of variance for Exps B2 plus B3 the presence of motile spermatozoa caused the incorporation of substrates into lipid $(P<0.01)$, but this was due to the incorporation of glycerol while the cells were cooling from 15 to $5^{\circ} \mathrm{C}$ (substrate $\times$ stage $\times$ presence of motile cells interaction: $P<0.05$ ).

Lactate levels were measured by enzyme assays on initial aliquots and after the three cooling stages. This was done both on the material from the experimental incubation flasks and on aliquots being cooled routinely in test-tubes for later stages. Mean ( \pm s.e.m.) values for the lactate accumulated in flasks by 3 replicates of each of 2 ejaculates by the end of stage 1 (i.e. cooling from 28 to $15^{\circ} \mathrm{C}$ ) and stage 2 (i.e. cooling from 15 to $5^{\circ} \mathrm{C}$ ) were $32 \pm 3.8$ and $77 \pm 4.8$ $\mathrm{nmol} / 10^{8}$ motile spermatozoa respectively. Under the more anaerobic conditions of cooling in test-tubes 3 replicates of each of 3 ejaculates had accumulated $149 \pm 13.0$ and $133 \pm 12.5$ $\mathrm{nmol} / 10^{8}$ motile spermatozoa after stages 1 and 2 respectively. This was greater than the amount in the flasks $(P<0.01)$ but showed that net accumulation of lactate did not occur during stage 2 of the routine cooling technique.

Table 1. The conversion of glucose and glycerol to $\mathrm{CO}_{2}$ and lipid curing the stages of the cooling process for storage of boar spermatozoa

\begin{tabular}{cccccccc}
\hline & & \multicolumn{7}{c}{ Temperature } \\
\cline { 3 - 7 } Substrate & Metabolite & 28 to $15^{\circ} \mathrm{C}$ & $P$ & 15 to $5^{\circ} \mathrm{C}$ & $P$ & 5 to $-196^{\circ} \mathrm{C}$ & $P$ \\
\hline \multirow{2}{*}{ Glucose } & $\mathrm{CO}_{2}$ & $1650 \pm 332$ & $<0.01$ & $91 \pm 18$ & $<0.01$ & - & \\
& $\mathrm{Lipid}^{*}$ Glycerol & $50 \pm 12$ & $<0.05$ & $1 \pm 4$ & N.S. & $3 \pm 3$ & N.S. \\
& $\mathrm{CO}_{2}$ & - & & $290 \pm 110$ & $=0.05$ & - & \\
& Lipid & - & & $11 \pm 2$ & $<0.01$ & $3 \pm 2$ & N.S. \\
\hline
\end{tabular}

Values are mean \pm s.e.m. for 3 replicates of each of 4 ejaculates expressed as ng carbon atoms $/ 10^{9}$ motile spermatozoa (paired $t$ test against background values). 


\section{Experiment C: metabolism of boar spermatozoa before and after storage at $-196^{\circ} \mathrm{C}$}

Results for the metabolic parameters measured with 2 replicates from each of 4 ejaculates are summarized in Tables 2 and 3. There were fewer motile cells after storage $(22 \pm 9 \%)$ than before $(73 \pm 5 \%)$. Because metabolism continued during the cooling processes there was more lactate present with the thawed cells at the start of incubation. Total lactate accumulated (i.e. enzyme assay) was greater $(P<0.001)$ with the thawed cells $\left(1071 \pm 331 \mathrm{nmol} / 10^{8}\right.$ motile cells in $3 \mathrm{~h}$ ) than with the recently ejaculated cells $\left(676 \pm 164 \mathrm{nmol} / 10^{8}\right.$ motile cells in $\left.3 \mathrm{~h}\right)$. However, lactate accumulated from glucose was less $(P<0.01)$ with the thawed spermatozoa than with the recently ejaculated cells ( $78 \pm 22$ compared with $178 \pm 28 \mathrm{nmol} / 10^{8}$ motile cells in $3 \mathrm{~h}$ ). The decrease in the oxidation of glucose to $\mathrm{CO}_{2}$ was more pronounced (Table 2) than the decrease in the oxidation of glycerol (substrate $\times$ storage interaction: $P<0.01$ ). There was no significant change in the amounts of $\mathrm{CO}_{2}$ produced from $\left[1-{ }^{14} \mathrm{C}\right]$ lactate or $\left[2-{ }^{14} \mathrm{C}\right]$ lactate and no measurable formation of $\mathrm{CO}_{2}$ from citrate occurred with fresh or thawed spermatozoa. Fixation of $\mathrm{CO}_{2}$ from sodium $\left[{ }^{14} \mathrm{C}\right]$ bicarbonate was greater than the background radiation $(P<0.05)$ but was not examined further as the errors involved were too large. Fresh cells incorporated similar amounts of glucose and glycerol into lipid, but the stored cells incorporated more glycerol than glucose (substrate $\times$ storage interaction: $P<0.01$ ).

Despite the large standard errors, storage altered the pattern of incorporation of $\left[\mathrm{U}-{ }^{14} \mathrm{C}\right]-$ stearic and $\left[\mathrm{U}^{14} \mathrm{C}\right]$ palmitic acids into the lipid classes during incubation (Table 3 ). Stored cells incorporated less stearic acid into phosphatidyl choline. The proportion of incorporated stearic and palmitic acids that was in the total phospholipid decreased in stored cells.

Table 2. Metabolism of boar spermatozoa before and after storage in liquid nitrogen (mean \pm s.e.m. of 2 replicates for each of 4 ejaculates expressed $/ 10^{8}$ motile spermatozoa $/ 3 \mathrm{~h}$ at $37^{\circ} \mathrm{C}$ )

\begin{tabular}{|c|c|c|c|c|}
\hline \multirow[b]{2}{*}{ Substrate } & \multicolumn{2}{|c|}{$\begin{array}{l}\mathrm{CO}_{2} \text { formed from substrate } \\
(\mathrm{nmol})\end{array}$} & \multicolumn{2}{|c|}{$\begin{array}{l}\text { Substrated converted to lipid } \\
\text { (ng carbon atoms) }\end{array}$} \\
\hline & Fresh cells & Stored cells & Fresh cells & Stored cells \\
\hline Glucose & $1162 \pm 478$ & $138 \pm 66$ & $5 \cdot 31 \pm 2 \cdot 67$ & $2.33 \pm 1.25$ \\
\hline Glycerol & $895 \pm 198$ & $348 \pm 173$ & $8.65 \pm 1.83$ & $15 \cdot 16 \pm 2 \cdot 78$ \\
\hline$\left[1{ }^{14} \mathrm{C}\right]$ Lactate & $305 \pm 222$ & $354 \pm 93$ & 二 & - \\
\hline$\left[2-{ }^{14} \mathrm{C}\right]$ Lactate & $317 \pm 228$ & $267 \pm 104$ & - & - \\
\hline
\end{tabular}

Table 3. Incorporation of $\left[\mathrm{U}^{14} \mathrm{C}\right]$ palmitic and $\left[\mathrm{U}^{14} \mathrm{C}\right]$ stearic acids into lipids by boar spermatozoa before and after storage in liquid nitrogen (mean \pm s.e.m., $n=4$, expressed as percentage of substrate incorporated during incubation for $3 \mathrm{~h}$ at $37^{\circ} \mathrm{C}$ )

\begin{tabular}{|c|c|c|c|c|}
\hline \multirow[b]{2}{*}{ Fraction } & \multicolumn{2}{|c|}{ Palmitic acid (\%) } & \multicolumn{2}{|c|}{ Stearic acid (\%) } \\
\hline & $\begin{array}{l}\text { Fresh } \\
\text { sperm, }\end{array}$ & $\begin{array}{l}\text { Stored } \\
\text { sperm. }\end{array}$ & $\begin{array}{l}\text { Fresh } \\
\text { sperm. }\end{array}$ & $\begin{array}{l}\text { Stored } \\
\text { sperm. }\end{array}$ \\
\hline Sphingomyelin & $1.24 \pm 0.63$ & $0.99 \pm 0.15$ & $2.98 \pm 0.46$ & $2.21 \pm 0.51$ \\
\hline Phosphatidyl choline & $11.78 \pm 1.42$ & $8 \cdot 10 \pm 1 \cdot 20$ & $7.43 \pm 0.30$ & $5 \cdot 31 \pm 0.40^{*}$ \\
\hline $\begin{array}{l}\text { Phosphatidic acid }+ \\
\text { phosphatidyl serine }+ \\
\text { phosphatidyl inositol }\end{array}$ & $15.47 \pm 1.95$ & $11.63 \pm 1.31$ & $28 \cdot 18 \pm 1 \cdot 26$ & $23.91 \pm 0.89$ \\
\hline Phosphatidyl ethanolamine & $0.83 \pm 0.08$ & $0.74 \pm 0.14$ & $2.57 \pm 0.38$ & $2.31 \pm 0.46$ \\
\hline Diglycerides $(1,2)+$ cholesterol & $63.28 \pm 1.80$ & $66.61 \pm 1.31$ & $50 \cdot 68 \pm 4.71$ & $54.92 \pm 2.49$ \\
\hline Diglycerides $(1,3)$ & $7.42 \pm 0.69$ & $11.94 \pm 1.64$ & $8 \cdot 16 \pm 3.74$ & $11 \cdot 33 \pm 2.50$ \\
\hline Total phospholipids & $29 \cdot 31 \pm 1 \cdot 11$ & $21.45 \pm 1 \cdot 10^{* *}$ & $41 \cdot 15 \pm 1 \cdot 64$ & $33.74 \pm 1.04^{*}$ \\
\hline
\end{tabular}

Significantly different from value for fresh spermatozoa: ${ }^{*} P<0.05,{ }^{* *} P<0.005$.

$\uparrow$ Contaminated with phosphatidyl choline. 


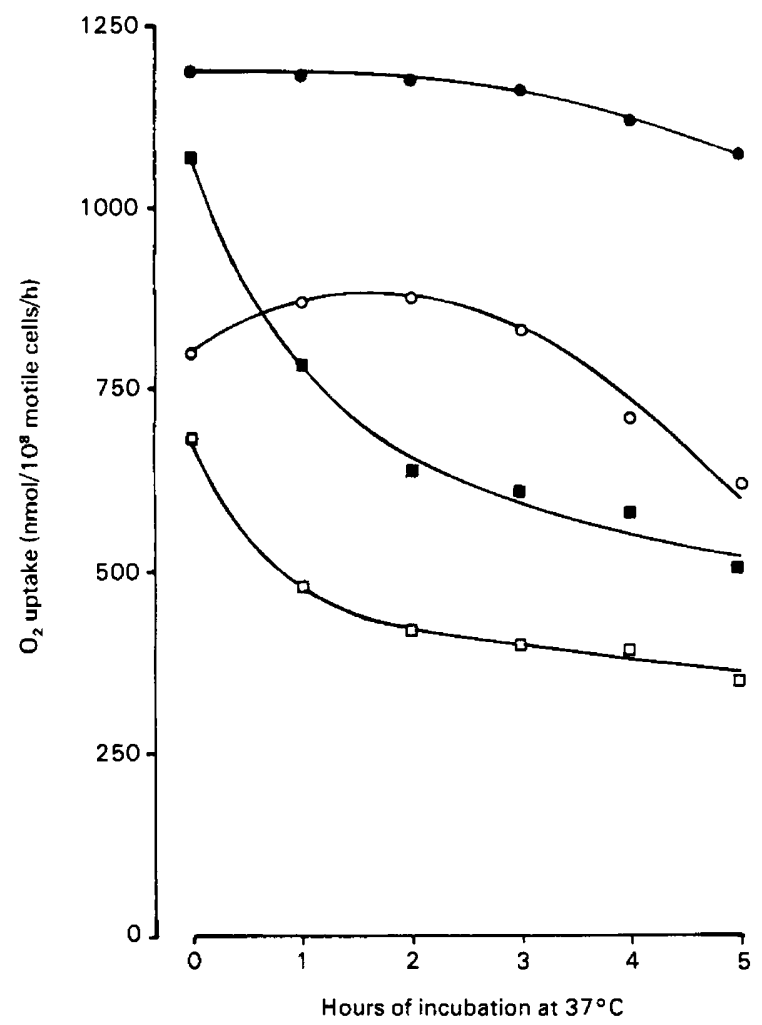

Text-fig. 1. The effect of storage in liquid nitrogen on the oxygen uptake of boar spermatozoa (freshly collected $(O)$ and thawed $(\square)$, and with $(O, \square) 0.6 \mathrm{~mm}$-caffeine) added during measurement of oxygen uptake. Values are the means for 6 ejaculates. From the analysis of variance the s.e. of the difference between means for the storage $\times$ caffeine $x$ hours of incubation interaction $=0.053$ ( 15 d.f.).

In a separate experiment with 6 ejaculates, freshly collected spermatozoa showed a slight rise in oxygen uptake during the first $2 \mathrm{~h}$ (Text-fig. 1), whereas the oxygen consumption of thawed cells fell most rapidly at this time (storage $\times$ hours of incubation interaction: $P<0.001$ ). The addition of caffeine to sub-samples increased oxygen consumption for fresh and thawed cells $(P<0.01)$. The effect was maintained on the fresh spermatozoa, but declined with time for the thawed cells, as did the oxygen uptake of unstimulated thawed cells (storage $\times$ caffeine $\times$ hours of incubation interaction: $P<0.01$ ). Some of the ejaculates were incubated for a further $3 \mathrm{~h}$ and the trends were continued.

\section{Discussion}

The alteration in cell metabolism with increasing concentration of glycerol meant that comparisons of the metabolism of glucose and glycerol during the processing of semen could not be inferred from comparisons when less substrate was used. This increased the difficulty of the experiments with respect both to specific activities and to the number of competing substrates (O'Shea \& Wales, 1966). The relatively low specific activity of the bicarbonate $(0.1 \mathrm{mCi} / \mathrm{mmol})$ is the most likely reason for the failure to observe any effects on $\mathrm{CO}_{2}$ fixation. Release of metabolizable substrates by spermatozoa rendered immotile during freezing changes slightly the levels of substrates available to the motile spermatozoa remaining after thawing (Exp. A). 
A major metabolite accumulated during processing for storage was lactic acid, a direct competitor of glucose oxidation (O'Shea \& Wales, 1966). This increased pool of lactate would be important with respect to the lack of effect of storage on lactate oxidation. The data for lactate accumulation during the cooling processes show that the use of flasks for the metabolic measurements altered the environment and metabolism of the spermatozoa.

Penetration rates of glycerol into spermatozoa appear to differ among species, but penetration into boar spermatozoa seems to be rapid, at least at the temperatures at which it was added in the present experiments (O'Dell, Flipse \& Almquist, 1956; Mann \& White, 1957; Sherman, 1963; Wilmut, 1971; Berndtson \& Foote, 1972). This ready penetration into boar spermatozoa may be associated with the increased glycerol utilization which accompanies increased glycerol concentration, and with the preferential usage of glycerol rather than glucose by cooled and thawed cells. Ackerman (1970) has reported that human spermatozoa subjected to freezing utilize more glycerol and it has been suggested (Hood, Foley \& Martin, 1970) that in cold-shock there is a breakdown in the mechanisms providing energy for the maintenance of the cell's internal environment, possibly involving damage to the membranes. Glycerol metabolism could provide energy to such cells. Although this metabolic utilization could be a factor in the protection exerted by glycerol, its physico-chemical properties seem to be more important in cryoprotection (Smith, 1961; Sherman, 1964; Orii \& Morita, 1977).

One puzzling observation is the increased accumulation of lactate by the thawed cells, although this has also been observed with human spermatozoa (Ackerman, 1968). In the present study the accumulation could have been due to metabolism of immotile cells because the results were expressed per $10^{8}$ motile cells. Brooks \& Mann (1973) have shown that there was a large depression of glycolysis in cold-shocked, immobilized spermatozoa, but that the decrease in pyruvate metabolism was much less. In the present study glycolysis was markedly depressed by storage. It is therefore possible that increased lactate production from substrates other than glucose and the preferential utilization of glycerol by thawed cells are functions of severely damaged spermatozoa, rather than being related to the metabolism of the remaining motile spermatozoa.

That membrane damage occurs during storage has been inferred from the loss of intracellular constituents (Mann, 1964; Graham \& Pace, 1967; Darin-Bennett, Poulos \& White, 1973), from the increased membrane permeability to stains (Easley, Mayer \& Bogart, 1942; Mann, 1964), and from morphological changes (e.g. Healey, 1969; Kann \& Hollande, 1972; Yasuda \& Tanimura, 1974; Larsson \& Einarsson, 1975). Such membrane damage is paralleled by loss of lipid during cold-shock or freezing-thawing (Hartree \& Mann, 1959; Pickett \& Komarek, 1967; Darin-Bennett et al., 1973). Boar spermatozoa show a smaller quantitative loss of phospholipids than do bull spermatozoa but, because of the specific phospholipids lost, this loss may be associated more closely with acrosome damage in boar spermatozoa (Darin-Bennett et al., 1973). The major component released from boar spermatozoa was phosphatidyl choline (Darin-Bennett et al., 1973), and this may be related to the decreased relative incorporation of stearic acid into phosphatidyl choline and of both stearic and palmitic acids into phospholipids in general. Although not significant the apparent decline in incorporation of the fatty acids into the fraction containing phosphatidyl serine may be related to the protection by phosphatidyl serine of boar spermatozoa against cold shock (Butler \& Roberts, 1975). Incorporation of fatty acids into membrane lipids may be an aspect of the protective function of egg yolk, but because of its complex nature egg yolk is likely to have more than one function. Metabolic effects could be separate from such actions as membrane attachment (Watson, 1975). A similar examination of glycerol incorporation into lipids would be of interest, although repair of freezing damage, as occurs in other cells (McGann, Kruuv \& Frey, 1972), has not been shown to occur in spermatozoa.

The relative amounts of the fatty acids incorporated into phospholipids or neutral lipids differ in boar spermatozoa from the values reported for bull and ram spermatozoa (Mills \& 
Scott, 1969), in that relatively more isotope became incorporated into phospholipids in the boar spermatozoa. In bull and ram spermatozoa, phosphatidyl inositol had an especially high incorporation of fatty acids (Neill \& Masters, 1972, 1973), and a similar pattern seems to exist in boar spermatozoa.

The oxygen uptake of fresh spermatozoa was maintained for up to $8 \mathrm{~h}$ in the presence of 42 $47 \mathrm{mM}$-glycerol in the present experiments although reports of detrimental effects on boar spermatozoa have usually involved high levels of glycerol (e.g. Sanford, King \& MacPherson, 1972). Although the initial oxygen uptake of stored cells is not much less than that of fresh spermatozoa, the more rapid decline during incubation of their motility and metabolism has important practical implications (White, Blackshaw \& Emmens, 1954). The increased oxygen uptake of stored cells when caffeine is added is interesting but the transient nature of this stimulation removes some of its possible value. The gradual decrease in the ability of the stored cells to be stimulated by caffeine may be related to the toxic effect of caffeine when time of incubation with caffeine is increased (Paquignon \& Dacheux, 1977).

\section{References}

Ackerman, D.R. (1968) The effect of cooling and freezing on the aerobic and anaerobic lactic acid production of human semen. Fert. Steril. 19, 123128.

Ackerman, D.R. (1970) Glycerol metabolism in untreated, cold-shocked and frozen human spermatozoa. Cryobiology 7, 145-147.

Berndtson, W.E. \& Foote, R.H. (1972) Bovine sperm volume at various intervals after addition of glycerol at $5^{\circ} \mathrm{C}$. Cryobiology $9,29-33$.

Brooks, D.E. \& Mann, T. (1973) Pyruvate metabolism in boar spermatozoa. J. Reprod. Fert. 34, 105-119.

Butler, W.J. \& Roberts, T.K. (1975) Effects of some phosphatidyl compounds on boar spermatozoa following cold shock or slow cooling. J. Reprod. Fert. 43, $183-187$.

Dacheux, J.-L., O'Shea, T. \& Paquignon, M. (1979) Effects of osmolality, bicarbonate and buffer on the metabolism and motility of testicular, epididymal and ejaculated spermatozoa of boars. J. Reprod. Fert. 55, 287-296.

Darin-Bennett, A., Poulos, A. \& White, I.G. (1973) The effect of cold shock and freeze-thawing on release of phospholipids by ram, bull, and boar spermatozoa. Aust. J. biol. Sci. 26, 1409-1420.

Easley, G.T., Mayer, D.T. \& Bogart, R. (1942) The influence of diluters, rate of cooling and storage temperature upon survival of sperm. Am. J. vet. Res. 3, 358-363.

Einarsson, D. (1973) Deep freezing of boar spermatozoa. Wld Rev. Anim. Prod. 9, 45-51.

Graham, E.F. \& Pace, M.M. (1967) Some biochemical changes in spermatozoa due to freezing. Cryobiology 4, 75-84.

Hartree, E.F. \& Mann, T. (1959) Plasmalogen in ram semen, and its role in sperm metabolism. Biochem. $J$. 71, 423-434.

Healey, P. (1969) Effect of freezing on the ultrastructure of the spermatozoon of some domestic animals. $J$. Reprod. Fert. 18, 21-27.

Hood, R.D., Foley, C.W. \& Martin, T.G. (1970) Effects of cold-shock, dilution, glycerol and dimethyl sulfoxide on cation concentration in porcine spermatozoa. J. Anim. Sci. 30, 91-94.
Kann, M.L. \& Hollande, E. (1972) Modifications cytochimiques du glycolemme ("cell coai") du spermatozoïde de taureau avant et après congélation. Proc. 7th Int. Congr. Anim. Reprod. \& A.I., Munich, Vol. 2, pp. 1325-1329.

Larsson, K. \& Einarsson, S. (1975) Fertility and postthawing characteristics of deep frozen boar spermatozoa. Andrologia 7, 25-30.

Mann, T. (1964) Biochemistry of Semen and the Male Reproductive Tract. Methuen, London.

Mann, T. \& White, I.G. (1957) Glycerol metabolism by spermatozoa. Biochem. J. 65, 634-639.

McGann, L.E., Kruuv, J. \& Frey, H.E. (1972) Repair of freezing damage in mammalian cells. Cryobiology $\mathbf{9}$, 496-501.

Mills, S.C. \& Scott, T.W. (1969) Metabolism of fatty acids by testicular and ejaculated ram spermatozoa. J. Reprod. Fert. 18, 367-369.

Neill, A.R. \& Masters, C.J. (1972) Metabolism of fatty acids by bull spermatozoa. Biochem. J. 127, 375385.

Neill, A.R. \& Masters, C.J. (1973) Metabolism of fatty acids by ovine spermatozoa. J. Reprod. Fert. 34, 279-287.

O'Dell, W.T., Flipse, R.J. \& Almquist, J.O. (1956) Metabolism of bovine semen. III. Uptake and metabolic utilization of glycerol-1-C $\mathrm{C}^{14}$ by bovine spermatozoa. J. Dairy Sci. 39, 214-218.

Orii, Y. \& Morita, M. (1977) Measurement of the pH of frozen buffer solutions by using $\mathrm{pH}$ indicators. $J$. Biochem. 81, 163-168.

O'Shea, T. \& Wales, R.G. (1966) The aerobic metabolism of ram spermatozoa. J. Reprod. Fert. 11, 263273.

O'Shea, T. \& Wales, R. G. (1970) Studies of the fixation of carbon dioxide by washed ram spermatozoa. Aust. J. biol. Sci. 23, 889-901.

Osinowo, O. \& Salamon, S. (1976) Fertility test of frozen boar semen. Aust. J. biol. Sci. 29, 335-339.

Paquignon, M. \& Courot, M. (1975) Survie des spermatozoides de verrat après décongélation. Effet du rythme de collectes, de la concentration et du taux de glycérol. Annls Biol. anim. Biochim. Biophys. 15, 517-523. 
Paquignon, M. \& Courot, M. (1976) Fertilizing capacity of frozen boar spermatozoa. Proc. 8th Int. Congr. Anim. Reprod. \& A.I., Krakow, Vol. 4, pp. 10411044.

Paquignon, M. \& Dacheux, J.-L. (1977) Stimulating and inhibiting effects of different concentrations of caffeine on the oxygen uptake of porcine ejaculated spermatozoa. IRCS J. (Biochem. Drug Metab. Expl Anim. Pharmacol. Physiol. Reprod.) 5, 285.

Paquignon, M. \& du Mesnil du Buisson, F. (1973) Fertilité et prolificité de truies inséminées avec du sperme congelè. Journées de la Recherche Porcine en France, pp. 49-57.

Pickett, B.W. \& Komarek, RJ. (1967) Effect of cold shock and freezing on loss of lipid from spermatozoa. J. Dairy Sci. 50, 753-757.

Polge, C., Salamon, S. \& Wilmut, I. (1970) Fertilising capacity of frozen boar semen following surgical insemination. Vet. Rec. 87, 424-428.

Pursel, V.G. \& Johnson, L.A. (1975) Freezing of boar spermatozoa: fertilizing capacity with concentrated semen and a new thawing procedure. J. Anim. Sci. 40, 99-102.

Robinson, J. \& Cooper, J. M. (1970) Method of determining $\mathrm{O}_{2}$ concentration of biological media suitable for calibration of the $\mathrm{O}_{2}$ electrode. Analyt. Biochem. 33, 390-399.
Sanford, L.M., King, G.J. \& MacPherson, J.W. (1972) Influence of glycerol concentration and freezing to $-79^{\circ} \mathrm{C}$ on oxygen uptake and livability of boar and bull spermatozoa. Can. J. Anim. Sci. 52, 65-72.

Sherman, J.K. (1963) Questionable protection by intracellular glycerol during freezing and thawing. $J$. cell. comp. Physiol. 61, 67-83.

Sherman, J.K. (1964) Low temperature research on spermatozoa and eggs. Cryobiology 1, 103-129.

Smith, A.U. (1961) Biological Effects of Freezing and Thawing. Edward Arnold, London.

Watson, P. F. (1975) The interaction of egg yolk and ram spermatozoa studied with a fluorescent probe. $J$. Reprod. Fert. 42, 105-111.

White, I.G., Blackshaw, A. W. \& Emmens, C.W. (1954) Metabolic and motility studies relating to the low temperature storage of ram and bull spermatozoa. Aust. vet. J. 30, 85-94.

Wilmut, I. (1971) The preservation of boar semen. Ph.D. thesis, University of Cambridge. [Cited by Wilmut et al., 1973.]

Wilmut, I. \& Polge, C. (1974) The fertilizing capacity of boar semen stored in the presence of glycerol at 20,5 and $-79^{\circ} \mathrm{C}$. J. Reprod. Fert. 38, 105-113.

Yasuda, Y. \& Tanimura, I. (1974) Scanning electron microscopy of boar spermatozoa before and after frozen-thawed treatment. Int.J. Fert. 19, 149-158.

Received 3 January 1978 